\title{
Vitamin K-dependent carboxylase
}

Citation for published version (APA):

de Boer-van den Berg, M., Ulrich, M. M. W., Hemker, H. C., Soute, B. A. M., \& Vermeer, C. (1985).

Vitamin K-dependent carboxylase: The carboxylation of exogenous substrates in different systems. Biochimica et Biophysica Acta (BBA) - Protein Structure and Molecular Enzymology, 831(1), 94-98. https://doi.org/10.1016/0167-4838(85)90154-2

Document status and date:

Published: 20/09/1985

DOI:

10.1016/0167-4838(85)90154-2

Document Version:

Publisher's PDF, also known as Version of record

\section{Please check the document version of this publication:}

- A submitted manuscript is the version of the article upon submission and before peer-review. There can be important differences between the submitted version and the official published version of record.

People interested in the research are advised to contact the author for the final version of the publication, or visit the DOI to the publisher's website.

- The final author version and the galley proof are versions of the publication after peer review.

- The final published version features the final layout of the paper including the volume, issue and page numbers.

Link to publication

\footnotetext{
General rights rights.

- You may freely distribute the URL identifying the publication in the public portal. please follow below link for the End User Agreement:

www.umlib.nl/taverne-license

Take down policy

If you believe that this document breaches copyright please contact us at:

repository@maastrichtuniversity.nl

providing details and we will investigate your claim.
}

Copyright and moral rights for the publications made accessible in the public portal are retained by the authors and/or other copyright owners and it is a condition of accessing publications that users recognise and abide by the legal requirements associated with these

- Users may download and print one copy of any publication from the public portal for the purpose of private study or research.

- You may not further distribute the material or use it for any profit-making activity or commercial gain

If the publication is distributed under the terms of Article $25 \mathrm{fa}$ of the Dutch Copyright Act, indicated by the "Taverne" license above, 


\title{
Vitamin K-dependent carboxylase: the carboxylation of exogenous substrates in different systems
}

\author{
Marian A.G. de Boer-van den Berg, Magda M.W. Ulrich, \\ H. Coenraad Hemker, Berry A.M. Soute and Cees Vermeer * \\ Department of Biochemistry, Biomedical Center, State University of Limburg, P.O. Box 616, 6200 MD Maastricht \\ (The Netherlands)
}

(Received February 18th, 1985)

Key words: Vitamin K; Carboxylase; Warfarin; Descarboxyfactor; (Bovine liver)

Two types of solid-phase carboxylase, SPC-II and SPC-X, have been prepared from the livers of warfarintreated cows. Their enzymatic activities were compared with substrate-free carboxylase in microsomes from normal cows and substrate-bound carboxylase in microsomes from warfarin-treated cows. A number of exogenous substrates for carboxylase have been purified and tested. We found that large substrates, such as descarboxyprothrombin, are carboxylated only by substrate-free carboxylase and not by the substrate-bound enzyme. No differences in apparent $K_{\mathrm{m}}$ values between solid-phase carboxylases II and X were observed.

\section{Introduction}

Vitamin K-dependent carboxylase is a microsomal enzyme system involved in the post-translational modification of proteins [1,2]. Initially, the system was thought to be present uniquely in liver, but later on carboxylase was also detected in other tissues such as lung, spleen, kidney, testis and arterial vessel wall $[3,4]$. Whether all these carboxylases are identical is still a matter of research. Contrarily, they also might form a family of isoenzymes, and it cannot even be excluded that different isoenzymes are present in one type of tissue.

Hepatic carboxylase is used in most studies concerning the vitamin $\mathrm{K}$-dependent reaction. The characteristics of the enzyme preparation may depend on the pretreatment of the donor animal and on the enzyme preparation procedure. Crude mi-

\footnotetext{
* To whom all correspondence should be addressed. Abbreviation: Chaps, 3-[(3-cholamidopropyl)-dimethylammonio]-1-propanesulfonate.
}

crosomal extracts from normal animals contain only a very small amount of endogenous substrate and therefore the preparation is called substratefree carboxylase [5], whereas substrate-bound carboxylase is obtained form the livers of warfarin-treated animals $[5,6]$. The endogenous substrate consists mainly of precursors of the coagulation factors II (prothrombin) and $X$ [7]. When the solubilized substrate-bound microsomes are extracted with Sepharose-linked antibodies against factor $\mathrm{X}$ [7] or prothrombin [8], two types of solid-phase carboxylase are obtained. They are designated SPC-X and SPC-II, respectively.

We have prepared these four types of carboxylase from bovine liver and we have compared their respective properties. The results of our investigations are presented in this paper.

\section{Materials and Methods}

Chemicals. Vitamin K-1 (Konakion) was obtained from Hoffmann-La Roche (Switzerland) and vitamin $\mathrm{K}$ hydroquinone was prepared as 
described previously [9]. The synthetic substrate Phe-Leu-Glu-Glu-Leu (FLEEL) was obtained from Vega Biochemicals (U.S.A.), $\mathrm{NaH}^{14} \mathrm{CO}_{3}$ $(40-60 \mathrm{Ci} / \mathrm{mol})$ from Amersham (U.K.) and Atomlight from New England Nuclear (F.R.G.). Warfarin, benzamidin, dithiothreitol, bovine serum albumin, Triton X-100 and Chaps were purchased from Sigma (U.S.A.). CNBr-activated Sepharose, Sephadexes G-25, G-100, G-200 and DEAE-Sephadex were obtained from Pharmacia (Sweden). The proteinases subtilisin and chymotrypsin were obtained from Boehringer (F.R.G.). All other chemicals were from Merck (F.R.G.).

Preparation of antibodies. Bovine prothrombin was prepared as described by Owen et al. [10] and antibodies against the purified antigen were raised in goats. Anti-prothrombin antibodies were specifically extracted from the immune serum with the aid of Sepharose-bound prothrombin and eluted with $3 \mathrm{M}$ KCNS. The purified antibodies gave single precipitin lines against normal reference plasma in an Ouchterlony diffusion test [11]. After dialysis against $0.15 \mathrm{M} \mathrm{NaCl} / 20 \mathrm{mM}$ Tris$\mathrm{HCl}(\mathrm{pH}$ 7.5), the antibodies were bound to CNBr-activated Sepharose (10-15 mg protein per $\mathrm{g}$ dry Sepharose). Bovine factor $\mathrm{X}$ was prepared as described by Fujikawa et al. [12] and Sepharosebound anti-factor $\mathrm{X}$ antibodies were prepared in a similar way as described for antiprothrombin. The Sepharose-bound antiprothrombin was able to extract prothrombin from normal bovine plasma without affecting the level of factor $X$ and vice versa.

Preparation of microsomal carboxylase. Cows were anticoagulated for 1 week by the oral administration of warfarin (10 mg/ kg body weight daily). Crude microsomes were prepared from the livers of normal and warfarin-treated cows as described earlier [5]. After three washing cycles the microsomes were suspended in buffer $\mathrm{A}(1 \mathrm{M} \mathrm{NaCl} / 0.05$ $\mathrm{M}$ Tris- $\mathrm{HCl}(\mathrm{pH} 7.5) / 1$ mM EDTA $/ 20 \%$ ethyleneglycol) to a concentration of $50 \mathrm{mg}$ protein per $\mathrm{ml}$ and stored at $-80^{\circ} \mathrm{C}$.

Preparation of solid-phase carboxylase. Microsomes from warfarin-treated cows were suspended in buffer A ( $50 \mathrm{mg}$ protein $/ \mathrm{ml}$ ) and solubilized by the addition of Chaps to a final concentration of $1 \%(\mathrm{w} / \mathrm{v})$. Non-solubilized material was spun down $(90 \mathrm{~min}$ at $100000 \times \mathrm{g})$ and the supernatant was supplemented with an equal volume of distilled water and $1 \mathrm{mg}$ sodium azide per $100 \mathrm{ml} .40 \mathrm{ml}$ of this preparation was incubated with $10 \mathrm{ml}$ Sepharose-bound antibodies against either prothrombin or factor X; this suspension was rotated end over end at $4^{\circ} \mathrm{C}$. A maximal amount of carboxylase activity was bound to the Sepharose after $24 \mathrm{~h}$ for SPC-X and after $3 \times 24 \mathrm{~h}$ for SPC-II. In the latter case the solubilized microsomes were refreshed after each period of $24 \mathrm{~h}$. After the complete incubation, the Sepharose beads were washed with buffer B $(0.1 \mathrm{M} \mathrm{NaCl} / 0.05 \mathrm{M}$ Tris- $\mathrm{HCl}(\mathrm{pH}$ 7.5)/1 mM EDTA), suspended in an equal volume of buffer B and stored until use at $-80^{\circ} \mathrm{C}$.

Measurement of carboxylase activity. The vitamin $\mathrm{K}$-dependent incorporation of ${ }^{14} \mathrm{CO}_{2}$ was measured by incubating $0.25 \mathrm{ml}$ reaction mixtures in buffer $\mathrm{B}$ containing $0.1 \mathrm{ml}$ solid-phase carboxylase (0.05 mg protein) $0.01 \mathrm{mCi} \mathrm{NaH}{ }^{14} \mathrm{CO}_{3}, 8 \mathrm{mM}$ dithiothreitol, $0.2 \mathrm{mM}$ vitamin $\mathrm{K}$ hydroquinone and exogenous substrate as indicated. The tubes were sealed and incubated in a shaking water bath for $1 \mathrm{~h}$ at $25^{\circ} \mathrm{C}$ unless indicated otherwise. The incubation was stopped by adding $0.25 \mathrm{ml}$ ice-cold buffer A followed by centrifugation at $2000 \times \mathrm{g}$ for $10 \mathrm{~min}$ at $4^{\circ} \mathrm{C}$. An aliquot $(0.25 \mathrm{ml})$ of the supernatant was transferred to a counting vial and non-bound ${ }^{14} \mathrm{CO}_{2}$ was removed by adding $2 \mathrm{ml}$ trichloroacetic acid (5\%) and boiling the solution for $2 \mathrm{~min}$. The samples were supplemented with 10 $\mathrm{ml}$ Atomlight and counted in a Packard Tricarb scintillation counter. To measure the amount of endogenous substrate carboxylation, no exogenous substrate was added, and after incubation the complete reaction mixture was transferred to a counting vial and treated further as described above. When microsomes from normal or warfarin-treated cows were used $(5 \mathrm{mg}$ protein per $0.25 \mathrm{ml}), 0.4 \%$ Chaps $(\mathrm{w} / \mathrm{v})$ and $1 \mathrm{M}\left(\mathrm{NH}_{4}\right)_{2} \mathrm{SO}_{4}$ were added to the reaction mixture as described for solid-phase carboxylase. In all experiments, parallel incubations were performed in the absence of vitamin $\mathrm{K}$ hydroquinone and dithiothreitol; these blank values were subtracted.

Preparation of substrates. Descarboxyfactor II and descarboxyfactor $\mathrm{X}$ were prepared from the blood of warfarin-treated cows according to the methods of Stenflo and Ganrot [13] and Lindhout et al. [14], respectively. Fragment Su was prepared 
by digesting the descarboxyfactors with Sepharose-bound subtilisin; the fragments were purified by ion-exchange and size-exclusion chromatography [15]. The chymotryptic fragments 1-41 [16] were obtained by digestion of the decarboxyfactors with Sepharose-bound chymotrypsin and partly purified by ion-exchange chromatography. Decarboxylated bovine osteocalcin (49 amino acid residues) was prepared as described earlier [17].

Determination of apparent $K_{m}$ values. Solidphase carboxylase reaction mixtures containing varying substrate concentrations were incubated for $0,15,30,45$ and $60 \mathrm{~min}$. During these periods the reaction rates were linear in all experiments described in this paper. At least five different substrate concentrations were used in the range of 0.5-10 mM for F LEEL, 1-100 $\mu \mathrm{M}$ for the descarboxyfactors II and $\mathrm{X}$ and for decarboxylated osteocalcin and $0.1-10 \mu \mathrm{M}$ for the subtilisin fragments of the descarboxyfactors. The amounts of incorporated ${ }^{14} \mathrm{CO}_{2}$ in the absence of added substrate were subtracted. The inverse of the initial reaction rates thus obtained was plotted against the inverse substrate concentrations. From the resulting Lineweaver-Burk plot, the apparent Michaelis constant $\left(K_{\mathrm{m}}\right)$ was calculated according to the method of Eisenthal and Cornish-Bowden [18].

Other methods. Protein concentrations were determined according to Lowry et al. [19]. The protein content of solid-phase carboxylase was measured after its elution from the Sepharose beads with $6 \mathrm{M}$ urea in $2 \%$ sodium dodecyl sulphate. Protein-bound 4-carboxyglutamic acid residues were determined as described by Kuwada and Katayama [20].

\section{Results}

Solid-phase carboxylases II and X were prepared as described in Materials and Methods. The optimal reaction conditions for carboxylation were similar to those in the crude microsomal systems, except for the fact that in the solid-phase systems, detergents, even at low concentrations, acted in a strongly inhibitory manner. Although the two solid-phase carboxylases presumably contain different substrates, no differences between the complexed carboxylases could be observed. In both types of enzyme the endogenous substrates were carboxylated preferentially during the first $15-20$ min and after this period exogenous substrates such as FLEEL were carboxylated with a constant reaction rate for more than $2 \mathrm{~h}$. The lag-phase in carboxylation of exogenous substrates may be circumvented by preincubation of solid-phase carboxylase in the presence of vitamin $\mathrm{K}$ hydroquinone and non-labeled $\mathrm{NaHCO}_{3}$ for $1 \mathrm{~h}$. In the experiments described below, pre-incubated solidphase carboxylase was used.

To compare the affinities of the Sepharosebound enzymes, a number of carboxylatable substrates were prepared. Descarboxyfactors II and X were isolated from plasma of warfarin-treated cows and purified. Since thermal decarboxylation $[21,22]$ of normal prothrombin and factor X could not be reproducibly repeated, were have used descarboxyfactors throughout our experiments. Smaller substrates were obtained by subtilisin cleavage of descarboxyfactors which yields a carboxylatable peptide of 17 amino acid residues (fragment $\mathrm{Su}$ ). Furthermore, osteocalcin was isolated from bovine bone and decarboxylated in vitro. In none of these preparations could 4-carboxyglutamic acid be detected.

No differences between SPC-II and SPC-X were found (Table I). Moreover, the large substrates were not carboxylated at all. To exclude the possibility that the descarboxyfactors were bound by

TABLE I

KINETIC CONSTANTS OF VARIOUS SUBSTRATES FOR SOLID-PHASE CARBOXYLASES II AND X

The apparent $K_{\mathrm{m}}$ values were calculated from the initial carboxylation ratesat various concentrations of the substrate, as described in Materials and Methods. Abbreviations used: D-II, descarboxyfactor II; D-X, descarboxyfactor X; fr. Su, subtilisin fragment; D-osteocalcin, decarboxylated osteocalcin; n.m. not measurable.

\begin{tabular}{lll}
\hline Substrate & \multicolumn{2}{c}{$(\mathrm{mM})$} \\
\cline { 2 - 3 } & SPC-II & SPC-X \\
\hline D-II & n.m. & n.m. \\
D-X & n.m. & n.m. \\
D-II fr. Su & 0.0014 & 0.0013 \\
D-X fr. Su & 0.0013 & 0.0016 \\
D-osteocalcin & 0.036 & 0.045 \\
F LEEL & 3.1 & 2.7 \\
\hline
\end{tabular}


TABLE II

CARBOXYLATION OF EXOGENOUS SUBSTRATES BY SUBSTRATE-FREE MICROSOMES, SUBSTRATE-BOUND MICROSOMES AND SOLID-PHASE CARBOXYLASES

The carboxylation reaction was performed under standard conditions. The values are the means of triplicate measurements. fr. C.T. stands for chymotryptic fragment; for other abbreviations, see the text to Table I.

\begin{tabular}{|c|c|c|c|c|c|}
\hline \multirow[t]{2}{*}{ Substrate } & \multirow{2}{*}{$\begin{array}{l}\text { Concn. } \\
(\mathrm{mM})\end{array}$} & \multicolumn{4}{|c|}{${ }^{14} \mathrm{CO}_{2}$ incorporated $(\mathrm{dpm} / \mathrm{h})$} \\
\hline & & $\begin{array}{l}\text { substrate-free } \\
\text { microsomes }\end{array}$ & $\begin{array}{l}\text { substrate-bound } \\
\text { microsomes }\end{array}$ & SPC-II & SPC-X \\
\hline None & & 820 & 16200 & 90 & 110 \\
\hline D-II & 0.01 & 900 & 16080 & 90 & 105 \\
\hline D-II & 0.1 & 4020 & 16150 & 110 & 140 \\
\hline$D-X$ & 0.01 & 880 & 16200 & 100 & 110 \\
\hline$D-X$ & 0.1 & 3870 & 16000 & 110 & 120 \\
\hline D-II fr. Su & 0.01 & 25430 & 51380 & 4120 & 6970 \\
\hline $\mathrm{D}-\mathrm{X}$ fr. Su & 0.01 & 24340 & 48660 & 4530 & 6340 \\
\hline D-II fr. C.T. & 0.01 & 20060 & 38300 & 2260 & 2850 \\
\hline D-X fr. C.T. & 0.01 & 18680 & 27700 & 2120 & 2730 \\
\hline D-osteocalcin & 0.01 & 14920 & 35020 & 3740 & 4750 \\
\hline FLEEL & 0.01 & 830 & 16200 & 100 & 110 \\
\hline FLEEL & 1.6 & 35800 & 88600 & 5880 & 10720 \\
\hline
\end{tabular}

free antibodies on the Sepharose the solid-phase carboxylases were preincubated with either bovine prothrombin or factor $\mathrm{X}$ before addition of the descarboxyfactors. This treatment had no effect on the amount of carboxylation measured.

Since both solid-phase carboxylases are substrate-bound enzyme systems, we have checked whether the endogenous substrates might hamper the carboxylation of large exogenous substrates. For that purpose, we have compared the properties of substrate-free and substrate-bound carboxylase in detergent-solubilized microsomes from normal and warfarin-treated cows, respectively. Except for the substrates mentioned in Table I we have also used the carboxylatable chymotryptic cleavage product (41 residues) of the descarboxyfactors. The results of these experiments are shown in Table II. It is clear that the peptide substrates (up to 49 amino acid residues) were good substrates in both systems, whereas the protein substrates could be carboxylated only in substrate-free carboxylase.

\section{Discussion}

It has been shown earlier that with the aid of insolubilized antibodies against blood coagulation factor X, $65 \%$ of the substrate-bound carboxylase could be extracted from solubilized microsomes [7]. From the supernatant no more complexes could be bound with unsolubilized antifactor $\mathrm{X}$, but still $21 \%$ with antiprothrombin. Together with the analyses of the extracted proteins [7], these experiments strongly indicate that no prothrombin precursors occur in solid-phase carboxylase $X$ and vice versa. No indication was obtained of any difference between the carboxylases present in the two solid-phase systems, however.

On the other hand, we did find a difference between substrate-free and substrate-bound carboxylase. Large substrates such as descarboxyprothrombin and descarboxyfactor $\mathrm{X}$ were carboxylated, albeit poorly, in substrate-free carboxylase whereas in the substrate-bound systems (in neither solubilized microsomes nor solidphase carboxylase) these protein substrates were not carboxylated. From our work with solid-phase carboxylase $\mathrm{X}$ we know that even after completion of the carboxylation reaction the enzyme and its carboxylated endogenous substrate remain firmly complexed, although the carboxylation of small peptides such as FLEEL occurs uninhibited. The experiments shown in this paper clearly indicate that in substrate-bound carboxylase, possibly be- 
cause of sterical hindrance by the endogenous substrate, the carboxylation of exogenous substrates is hampered. Therefore, substrate-free carboxylase (from the liver of normal, non-treated animals) is the enzyme system of choice when the affinity of carboxylase for various substrates is investigated.

\section{Acknowledgements}

The authors wish to thank Mrs. M. Molenaarv.d. Voort for typing this manuscript. Our research is supported by grant MD 82145 from the Trombosestichting Nederland.

\section{References}

1 Suttie, J.W. (1980) CRC Crit. Rev. Biochem. 8, 191-223

2 Vermeer, C. (1984) Mol. Cell. Biochem. 61, 17-35

3 Buchtal, S.D. and Bell, R.G. (1983) Biochemistry 22, 1077-1082

4 Vermeer, C., Hendrix, H. and Daemen, M. (1982) FEBS Lett. 148, 317-320

5 Vermeer, C., Soute, B.A.M., De Metz, M. and Hemker, H.C. (1982) Biochim. Biophys. Acta 714, 316-365

6 Suttie, J.W., Lehrman, S.R., Geweke, L.O., Hageman, J.M. and Rich, D.H. (1979). Biochem. Biophys. Res. Commun. $86,500-507$

7 De Metz, M., Vermeer, C., Soute, B.A.M., Van Scharrenburg, G.J.M., Slotboom, A.J. and Hemker, H.C. (1981) FEBS Lett. 123, 215-218
8 Olson, R.E., Hall, A.L., Lee, F.C., Kappel, W.K., Meyer, R.G. and Bettger, W.J. (1983) in Posttranslational Covalent Modifications of Proteins (Johnson, B.C., ed.), pp. 295-319, Academic Press, New York

9 De Metz, M., Soute, B.A.M., Hemker, H.C. and Vermeer, C. (1983) Biochem. J. 209, 719-724

10 Owen, W.G., Esmon, C.T. and Jackson, C.M. (1974) J. Biol. Chem. 249, 594-605

11 Ouchterlony, O. (1962) Progr. Allergy 6, 130-154

12 Fujikawa, K., Legas, M.E. and Davie, E.W. (1972) Biochemistry $11,4882-4891$

13 Stenflo, J. and Ganrot, P.O. (1972) J. Biol. Chem. 247, 8161-8167

14 Lindhout, M.J., Kop-Klaassen, B.H.M., Kop, J.M.M. and Hemker, H.C. (1978) Biochim. Biophys. Acta 533, 302-317

15 Soute, B.A.M., Vermeer, C., De Metz, M., Hemker, H.C. and Lijnen, H.R. (1981) Biochim. Biophys. Acta 676 101-107

16 Dode, C., Thiesce, A., Labie, D. and Elion, J. (1981) Biochem. Biophys. Res. Commun. 103, 461-468

17 Vermeer, C., Soute, B.A.M., Hendrix, H. and De Boer-van den Berg, M.A.G. (1984) FEBS Lett. 165, 16-19

18 Eisenthal, R. and Cornish-Bowden, A. (1974) Biochem. J. 139, 715-720

19 Lowry, O.H., Rosebrough, N.J., Farr, A.L. and Randall, R.J. (1951) J. Biol. Chem. 193, 265-275

20 Kuwada, M. and Katayama, K. (1983) Anal. Biochem. 131, 173-179

21 Poser, J.W. and Price, P.A. (1979) J. Biol. Chem. 254 431-436

22 Tuhy, P.M., Bloom, J.W. and Mann, K.G. (1979) Biochemistry $18,5842-5848$ 